\title{
The Application Study on flipped Class in Western Economics Teaching --- Taking Independent College for Example
}

\author{
Guoyan Wu \\ Dongfang College,Shandong University of Finance and Economics, Tai'an 271000, China
}

Keywords: flipped class, western economics, teaching reform

\begin{abstract}
With the coming of the cloud era, information technology has changed our teaching model greatly, and traditional teaching model is facing great challenge today. In this case, the flips can be used as a reference for reform of traditional class. Through investigating the problems in the course of western economics teaching in the independent college, this task discusses the significance of flipped class in the teaching of western economics. The main purpose is to explore the problems which need to be noticed on the design and application of the teaching methods in the flipped class. And finally it is going to form an effective mode in teaching.
\end{abstract}

\section{An overview of the flipped class model}

As a new thing, there is still no strict definition in the sense of pedagogy for the flipped class. Many international and domestic academics use descriptive definition to explain the flipped class. After summarizing and analyzing many researchers' viewpoints, Bishop et al. think flipped class is a technology that includes the learning activities of interaction group at the classroom and bases the individualizing teaching of computer outside the classroom. The past definition is too broad to explain the flipped class with the limits. It excludes teaching activities without using video out of class, which makes the definition more pertinent and directional.

Yujiang Zhang, a domestic scholar, thinks that flipped class is a form of teaching. Teachers create videos, student watch videos at home or out of class, and then finally they communicate with each other and finish homework return to class. Ling Jin put forward that flipped class refers to the turning over the teaching structure which teachers teach in the classroom during the daytime and students go back home and do their homework at night. To construct the teaching structure which students absorb and master knowledge in the classroom during the daytime, and learn new knowledge at home during night. The above definition has been so universally acknowledged by domestic scholars.

\section{The difference between the flipped class and the traditional teaching model}

\subsection{The changes in the role of teachers and students}

The most difference between the traditional class and the flipped class is the role of the students and teachers and which embodies in the study. Since the birth of the school, Teacher talking and students listening is a traditional way we used to today's classroom. To a certain extent, it has had a profound influence on today's education, but it may in fact be stifling students' active exploration of knowledge. Students are listening in the classroom, and the teachers dominate knowledge and class. However, the students become the real master of learning in the flipped class, who actively explore knowledge and study the problems with teachers and classmates. Teachers become the guide of thought and the facilitator of learning. They are no longer the authority and owner of knowledge but the collaborators of students.

\subsection{The changes in the form and content of classroom teaching}

In the traditional class, teacher gives lecture in the class and students do their homework out of class. In this form of teaching, teachers` teaching is just for learning in class, and knowledge imparting become the center of all teaching activities. Students acceptance of knowledge is the center of learning activities. So the teacher is the master in classroom which becomes the battlefield 
for the students to test. Students have become the "container" who listen to teachers in class and complete their homework after class. The interaction between teachers and students in the classroom becomes much less. In the flipped class, students are regarded as the true cognitive subject of knowledge. Students are not like storehouse to storage knowledge, but actively explore knowledge. Students learn knowledge through various ways before class and have a certain understanding of knowledge. In classroom, students should carry on inquiry-learning with teachers and students and focus on theme of this lesson and the questions which left before the class.

\subsection{The changes in the assessment styles of teaching}

In traditional classroom, because imparting knowledge becomes the main task of teachers, mastering knowledge becomes the main learning activity of students, teaching evaluation just serving for their goal. The corresponding teaching evaluation adopts the traditional paper test and examines the overall development of the students with the results. The flipped class does not deny the traditional paper test which is only help teachers to know degree of the knowledge of students. The flipped class gives comprehensive remarks to all aspects of the students in the multiple perspectives so that it can realize the papillary whole development.

\section{The present situation and existing problems in Western Economics Teaching of Independent Colleges}

\subsection{Having deviated in teaching orientation and the goal of talents training}

The goal of talents training in independent college has positioned itself as application-oriented talents rather than academic one, which means that students can solve real problems after graduation and serving a social need. The application-oriented talents who are cultivated by the independent college have the necessary theoretical knowledge and practical ability of the application. In order to follow this position, talents training plan of the independent college are mainly representing the cultivation of practical operation ability. And it tends to practice credits and hours when setting of school hours. However, the teaching of western economics in independent colleges emphasis on traditional theory teaching, ignore the training of students' skills of problem-solving and deviate from the goal of talents training in independent colleges.

\subsection{The teaching way is poor and testing results is single}

At present, the teaching way of western economics in independent colleges mainly adopts that whole classroom inoculation, which focuses on teacher and centered on teaching points arranged by syllabus. It can lead the students to know how without knowing why, and do not understand the practical application behind the theory. This way ignores the training of students' independent thinking ability. The old way do not pay attention to the practical problems in the real economy, and emphasize that remember the model essays by rote. As a standard to weigh the validity of teaching, it is one of the most important means to test and assess the students' learning effect. At present, western economics always adopt examination papers as the methods of examination in the inspection link of teaching. This traditional method of examination results in the pattern of learning. The students memorize textbooks for the knowledge points, plan goal for deal with exam instead of cultivating practical ability. Investigations found that the current teaching and assessment methods are being heavily discounted on the effectiveness of teaching.

\subsection{The teaching resources is inadequate and the teaching theory and practice of instructional design is seriously out of line}

In the construction of teaching materials, so far it has not find any authority textbook applied to western economics in independent colleges. Most of the independent colleges are still using academic textbooks which value theory more than practice. In terms of teachers, the majority of independent colleges lack their own full-time teachers. The main force of teaching is the teachers from maternal schools or other universities. These teachers follow the syllabuses which are provincial or key universities in teaching without innovation, and value theory more than practice. In the course of teaching, teachers often use a large number of models to explain and prove rather than pay attention to the introduction and analysis of practical cases. These do not contribute to that students learn to use the theories to explain real economic problems. 


\subsection{The lack of learning motivation and participation among the students}

There exists a kind of similarity of students in independent colleges and that is low scores and poor foundations. Under the traditional teaching method, the students are lack of learning motivation and the initiative is poor. However current Western economics course teaching presents a learning state where teacher gives lecture and students listen to a great extent. In teaching practice, many teachers apply a mechanically fixed pattern, which leads the teaching process of western economics to be a pure basic theory and model. In courses, the teaching time is randomly chosen by the teachers themselves while the student is only passive learner. It is not only difficult to satisfy the needs of the students in the independent college, but also hard to combine their subjective initiative, as well as cultivate the students' creative spirit and practical ability.

\section{The application of flipped class in the teaching of western economics in Independent College}

\subsection{The teaching design of the flipped class}

\subsubsection{Preparation before class}

\subsubsection{The analysis of teaching targets}

The goal of teaching is to lead to the result anticipated through teaching activities. If we expect the students to know something through teaching, it is the first key thing that clarifying the teaching objectives. Only when the teaching goals are clear before the teaching, our teaching can be pertinent. Then it is clear which the specific teaching methods we should adopt. Some contents need inquiring teaching methods and the other need direct teaching. The analysis of teaching objectives before the flipped classroom teaching is not only beneficial what suit to direct teaching through the way of video, but also know what suit to achieve the best teaching effect through the way of cooperation between teachers and students. Clear teaching goals could avoid blindness and aimless in teaching.

\subsubsection{Selecting and making teaching video}

In the flipped class, video content is a deliver of humanity knowledge. Teaching video can be recorded by the chief course instructors in person or used excellent education resources online. In the process of recording teaching video, teachers should have a consideration for students to adapt to the learning methods and habits of different students. Next, we have to make a good job of video editing. Two teachers at Woodland Park High School recorded the teaching videos and distributed to students in the initial stage of flipped classroom. But they gradually found the value in video post-production. That allows teachers to correct errors in video production and avoid reproducing it. In the end, the video is published. Publishing it is to allow that students can watch the video. The biggest problem for teachers at this stage is which place the video is published so that students can watch it. It is necessary to according the specific circumstances of the local area, the school and the school students to do it.

\subsubsection{Training before class}

For the learning before class, teachers should design with rational and pertinence. And students should complete the tasks which are assigned by teachers, so as to enhance the consolidation of learning contents. At the same time, teachers are supposed to make full use of network technology to guide students to study. After reading the teaching video, the students need record the contents of the video and the question interacting with teachers, through the message board, chat room and other communication platforms. In this process, the teacher fully understands the students before the class, and finds out the difficulties in time. Then they can explain the problems in class.

\subsubsection{Teaching design in course}

\subsubsection{Determine problems and solve with communication}

Teachers need to find valuable problem according to the content of the courses, the video which students view and problems before class. Students choose the corresponding topics based on their understanding and interest. In this process, teachers should instruct students to select the subject with pertinence, and classify the students according to the subjects. It is not more than 6 people to control the number of students. Then, according to the difficulty and type of the problem, teachers should choose the collaborative division. 


\subsubsection{Complete homework with collaborative learning}

The collaborative learning should be strengthened in the design of western economics flipping classroom. Teachers need to catch the students' dynamics at any time and guide them in time. Everyone in the group should participate actively and think carefully. Teachers should join in students' discussion and the group cooperation activities, instead of standing by the classroom. When students meet problems in the discussion, teachers can give timely help to guide students to clarify knowledge. In this process, it will have big changes in students' critical thinking, classroom participation and attitude towards learning. They really push students into the dominant position of learning. When students really need learning, they will become the real master of the study, and have active learning. Teachers also change their roles from talking to the guiding. In the teaching mode of flipping classroom, the cooperative learning between students and students, students and teachers in the classroom is in the real sense.

\subsubsection{Achievement exhibition, evaluation, and exchanges}

In the flipped classroom teaching of western economic, students need to report, exchange learning experiences and share the solving way of problems in the classroom. The form of achievement communication can be varied. Students can share their learning experience through presentation, exhibition, debate or small competition. In the process of presentation, students or groups can get a deeper understanding through the comments of teachers and students. At the same time, they can learn the advantages of others by watching group presentations and make clear their strengths and weaknesses. Students constantly appreciate the pleasure of learning, and face their future learning with a positive optimism and self-confidence. In addition, the teaching evaluation system should be reformed. And it means pay attention to the results of learning, while also valuing evaluation of the learning process. The content of the evaluation involves various links in the process.

\subsection{Application notices for the teaching of western economics in the Independent College} 4.2.1 Teach video time should not be too long and pay attention to interest and Application

According to the study, the attention span of the college students is much longer than children, but it is still not more than twenty minutes. In the traditional classroom, when teachers continue to explain for forty-five minutes, it is too difficult for students to concentrate for longer periods of time. Students need to concentrate on teaching materials because the characteristics of independent colleges' students, the complex course of western economic and the various formulas. Therefore, teachers must pay attention to the quality of video selection and upload the video which are close to the life and easy to learn, interesting and appropriate time. In this project, teachers upload four videos which are about 15 minutes every week. Some videos explaining problems are not more than 5 minutes. At the same time, video values application, which is interspersed with FLASH animation to increase students' interest in learning. The video materials which are short, interesting and highly practical can also encourage teachers to ensure video and teaching quality. They will have more intense enthusiasm to face the teaching.

\subsubsection{Video content and teaching information pay attention to be clear and straightforward.}

The most important feature of the video which is produced by the founder and propagator in the flipped classroom is that the video can not see the face and body of the teacher, but can only see the hands. They write some symbols and learning patterns on the blackboard, and gradually fill the whole blackboard. At the same time, the teacher's voice will follow the writing. As a result, when recording video, it can refer to the teacher's hand, chalk and blackboard. Teachers should be careful not to wear watches, and there can be no other pictures or words that having the irrelevant with education content on the blackboard. There are no windows, teachers and other sundries in the video screen, which can effectively prevent students' attention transfer and promote the students to concentrate on the blackboard. Another advantage of video teaching is to make use of the randomness of time and place about network communication. Students can learn whenever and wherever.

\subsubsection{Test the results of students' achievement and give feedback in time}

After the end of the course, the teacher should upload the exercises on the platform, and request 
students to do the questions after class to test the learning effect. It should be noted that the upload time of exercises should be earlier than the upload time of video or different time after all Students watch videos, and ask students to finish them in a certain time period, and submit them to public mailboxes. The difficulty of the exercises should not be too high. It should be related to the life of the students and closely related to the content of the teaching video.

\section{References}

[1]. Jing Wang. The Application Study on flipped Class in Economics Teaching [J]. Policy Research \& Exploration. 2015(05)

[2]. Zhe Wang, Jian Zhou. The Revolution Study of Institutional Economics Teaching--- Based on Questionnaire of Institutional Economics Course.[J]. Journal of Agricultural University of Hebei(Agriculture and Forestry Education). 2007(04)

[3]. Ruirong Zhang, The Problems and Countermeasures of Western Economics Teaching[J]. Journal of Inner Mongolia Agricultural University(Social Science Edition) . 2015(04) 